\title{
The global society and its impact on public relations theorizing: Reflections on major macro trends
}

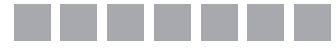 \\ Chiara Valentini \\ AARHUS UNIVERSITY, DENMARK \\ Dean Kruckeberg \\ UNIVERSITY OF NORTH CAROLINA AT CHARLOTIE, USA \\ Kenneth Starck \\ UNIVERSITY OF IOWA, USA
}

DOI: 10.19195/1899-5101.9.2(17).6

\begin{abstract}
This article contributes to the discussion on societal changes and their impact on communication disciplines by focusing on public relations and its role in contemporary global society. The thesis is that the public relations profession has been affected by contemporary societal changes that challenge the existing body of knowledge and its underpinning theories. To understand the role of public relations in 21st century global societies and pursuing future public relations theorizing, the authors argue it is paramount to comprehend which factors at macro, meso, and micro levels lie beneath the substantial changes in today's global society. The article presents and reflects on four major macro trends of contemporary global society and concludes with suggestions for future directions for public relations scholarship and practice that are rooted in the concept of community and the idea of being part of and at the service of a community.
\end{abstract}

KEYWORDS: public relations, global society, social change, communication technologies, marketization, community.

\section{INTRODUCTION}

Societies are living organisms that seek adaptation to survive and to compete with other societies. However, societies are becoming global due to the phenomenon of globalization that implies "the intensification of worldwide social relations which link distant localities in such a way that local happenings are shaped by events occurring many miles away and vice versa" (Giddens, 1990, p. 64). Valentini (2007) observed that people and organizations are affected by globalization to the extent that both can no longer think of themselves as mono- or bi-cultural. Although evidence shows that globalization is having an impact on how publics form, organ- 
ize, and act upon issues, this globalization has also created new challenges for communication professionals and brings into question what role different communication disciplines may have in global society.

This article contributes to the discussion on societal changes and their impact on communication disciplines by focusing on public relations and its role in contemporary global society. Public relations has increased its relevance in organizations (Moreno et al., 2014; Verčič et al., 2015), which play a vital role in the development of societies (Scherer \& Palazzo, 2011). As with other communication disciplines, the public relations profession has been affected by contemporary societal changes that challenge the existing body of knowledge and its underpinning theories. We discuss changes occurring in today's societies and how these changes may affect public relations practices and theories. We do this through a critical reading of the most relevant discussions in public relations (cf. Bardhan \& Weaver, 2011; Edwards, 2012; Edwards \& Hodges, 2011; Holtzhausen, 2011; Ihlen et al., 2009; McKie \& Munshi, 2009; Sriramesh \& Verčič, 2003, 2009), together with a range of examples. We reflect on four major macro trends happening worldwide. We do not intend to offer a deterministic overview or definitive prescriptions to a highly complex and ever-changing phenomenon. Rather, our purpose is to pinpoint some major trends that we believe will continue to impact public relations professional practice and to stimulate dialog and debate among public relations scholars as they pursue future public relations theorizing.

After providing a brief description of how societies throughout the world are changing by focusing on the concepts of globalization and information and communication technologies, which constitute the framework for our arguments, we offer some reflections on the limits of existing global public relations theories to tackle global society's continuous changes. We then discuss what we identify as the four macro trends that comprise today's public relations environment: social, political, economic, and cultural. We conclude with suggestions for future directions for public relations scholarship and practice.

\section{THE CONTEXT OF CONTEMPORARY CHANGES IN SOCIETIES WORLDWIDE}

To discuss changes in societies worldwide and how these changes affect and challenge public relations professional practitioners, we must examine how societies have changed and are continuing to change. Such an understanding is essential if public relations practice and theories are to reflect "the plurality of views in the field" (Edwards, 2012, p. 23) and to move away from a functionalist approach as an organization-oriented activity to become one that includes society-at-large, civil society, and nation building (e.g., Taylor, 2000, 2010; Taylor \& Doerfel, 2003).

Clearly, a comprehensive review on this subject is not possible within the scope of one article, which can only approximate and simplify a highly complex, heterogeneous, and fragmented phenomenon. Yet two concepts that are recognized and 
widely discussed across disciplines during the past twenty years need to be considered in understanding how societal changes may affect public relations practice and theories. These are: 1) globalization and 2) the emergence of new information and communication technologies. The two interrelated phenomena have created fundamental changes in societies worldwide, which must be examined and understood and which consequently are altering public relations practice and how practitioners must think about organizations, publics, and society, as well as about their own professional identity.

\section{Globalization and public relations theories}

The concept of globalization, its definition, and dimensions are widely interpreted and highly contested; nevertheless, the concept and its generally understood definition help explain changes occurring at individual, societal, and organizational levels. While many books have been written on globalization (e.g., Featherstone et al., 1995; Robertson, 1992; Tomlinson, 1999), we particularly appreciate the work of Scholte (2000), because it takes a critical view of debates on the subject. Furthermore, rather than proposing a static and ideologically driven definition, Scholte (2000) proposes a definition that is multiple-conceptual. Accordingly, globalization is seen as a "continuous process" rather than a "still status" (Scholte, 2000). Globalization encompasses internationalization - i.e., increased interactions and interdependence among people in different countries; liberalization - i.e., limited regulatory barriers to the transfer of resources among countries; universalization - i.e., a normative, general, worldwide law; westernization - i.e., homogenization of habits across the world that are often associated with the concept of Americanization; and deterritorialization - i.e., the loss of a specific geographical origin (see Scholte, 2000). Globalization, as several scholars have argued, has economic, governing, and societal implications (Robertson, 1992; Scholte, 2000), but it should not be considered to be a homogeneous and uniform phenomenon (Shome \& Hedge, 2002, p. 174). Often, globalization produces unequal transactional flows between Northern and Southern parts of the world (Dutta, 2012), and, when applied to describe the transformation of modern societies, it synthetizes societies into the deterritorialized, universal, and liberal concept of global society. A global society is a society in which goods and services are available to the same standard globally and are branded internationally (L'Etang, 2008). A global society:

[...] implies the promise of an international civil society, conducive to a new era of peace and democratization. (Berger, 2002, p. 2)

Yet according to Castells:

Not everything or everyone is globalized, but the global networks that structure the planet affect everything and everyone. (2008, p. 81) 
Globalization pushes societies toward more adaptation and universalization of their respective mores and norms. Robertson discusses globalization and global society as

[...] a sociocultural "system" which has resulted from the compression of - to the point that it increasingly imposes constraints upon, but also differentially empowers - civilizational cultures, national societies, intra- and cross-national movements and organizations, sub-societies and ethnic groups, intra-societal quasi-groups, individuals, and so on. (1992, p. 61)

Although the existence of a global society may be questioned, societies worldwide are nonetheless acquiring many common features. Globalization is creating both inward and outward forces, pulling publics in different directions and often in a chaotic manner. In the public relations literature, globalization is often seen as an extra variable, or even an addendum or subset, that challenges existing public relations theories, mostly because such theories were developed and constructed to explain social realities within specific cultural settings. A still limited, but nevertheless evolving, body of knowledge on what has been called 'global public relations' has emerged over the past twenty years (Sriramesh \& Verčič, 2003, 2009). Yet as some scholars have pointed out (Bardhan, 2011; Holtzhausen, 2011; L'Etang, 2012; Rittenhofer \& Valentini, 2015; Weaver, 2011), global public relations theorizing is mostly based on a systems-based understanding of society, culture, and publics. Thus, existing conceptualizations of "global public relations" have tended to reduce global public relations' complexity into predefined, often geographically based, categorizations of markets, cultures, and publics. With some exceptions (e.g., Holtzhausen, 2011; Rittenhofer \& Valentini, 2015), alternative views and approaches are limited in how to understand cultural diversity and to use this diversity as a resource, rather than seeing it as a problem for global public relations. In sum, globalization has posed some critical questions on the ways in which public relations is practiced across different physical, social, and ideological boundaries; however, the answers thus far provided are limited, and critical public relations scholars are calling for new directions for public relations theorizing in "global" societies (Edwards, 2012; Holtzhausen, 2011; Rittenhofer \& Valentini, 2015).

\section{New information and communication technologies and public relations theorizing}

Another phenomenon that is directly linked to globalization is the recent enhancement of information and communication technologies, consequently increasing their adoption by organizations and publics. Information and communication technologies, including rapid long-distance transportation and computer networks, refer to those that allow for fast synchronic or asynchronic communication exchanges among people across time and special boundaries (Castells, 2008). These technologies, as Vujnovic and Kruckeberg (2011) pointed out, have become a major driving force of globalization and global society. This is because such technologies, 
especially digital media, i.e., electronic media where data are stored in digital form, increasingly compress time and space and are less and less expensive, allowing for previously unimaginable opportunities for global networking. Also, the diffusion of such technologies has changed the ways in which people consume news and information, interact, and get to know other realities (Valentini, 2015).

In public relations literature, the diffusion and increasing use of new information and technologies among public relations practitioners, as well as among their publics, are received positively, with very few critical reflections on their side effects on human behaviors and relations. Social media are considered the new public sphere of conversations that increase the possibilities to foster dialogs between organizations and their publics (Valentini, 2015). Scholarly studies on the use of social media for public relations have exponentially increased, especially in the past ten years (Ye \& Ki, 2012). Yet the use of these technologies may have disruptive functions too, specifically when such technologies are used by people to diffuse rumors and voices with the sole purpose of damaging an organization's reputation (Coombs, 1998, 2002; Coombs \& Holladay, 2012). Despite this, public relations theorizing on social media remains limited (cf. Valentini, 2015). Public relations theorizing in the online sphere can be criticized for its lack of empiricallybased theories (Kent, 2010; Valentini, 2015), as well as for limited consideration of the implications of online activities on the real life of an individual and vice versa. Because real and virtual lives are more and more interconnected, it is hard to separate the outcomes of offline public relations efforts from those made online.

\section{NEW ENVIRONMENT, BUT OLD THEORIES, FOR PUBLIC RELATIONS}

We suggest that globalization is affecting societies worldwide and that the use of information and communication technologies can amplify the globalization processes. Further, we claim that these two phenomena are creating limitations to public relations theorizing. Global public relations scholars maintain that existing "theoretical frameworks inform the wide variety of global practice while supporting a flexible matrix that takes into account situational particulars" (Curtin \& Gaither, 2007, p. xii), whereas such situational particulars refer to differences in countries' political, economic, social, and cultural systems. Frequently, culture is added to existing public relations theories as an extra layer to understand and predict public behaviors and issue development. Global public relations studies dealing with culture typically encapsulate culture into a nation-state concept (cf. Hodges, 2012; Sriramesh \& Verčič, 2009) and treat it in a deterministic and functionalistic way, i.e., how to handle diversity, and not as a multifaceted concept that encompasses people who simultaneously identify with many cultures (Kent \& Taylor, 2011; Rittenhofer \& Valentini, 2015). This is a rather conservative approach that tends to encapsulate publics into predefined categories and that does not acknowledge global flux and sudden changes of norms and values as well as shifting public behaviors (cf. Ritten- 
hofer \& Valentini, 2015). Problems concerning the nature of public relations paradigms are also reflected in Radford's (2012) discussion of public relations as a profession defined through a predefined narrative. According to this view, public relations is "a way of talking about the world, the people in that world, and public relations' relationships with those people" (ibid., p. 50). Radford (2012) maintains that public relations scholars and practitioners are failing to recognize and to take into consideration multiple narratives in today's societies and how these narratives often conflict with one another. Failure to consider multiple narratives is also reflected in public relations paradigms that often fall short in considering multiple perspectives and/or deviating from standardized approaches. One scholar put it bluntly:

There is not enough scholarship from our field about some of the big issues facing the world such as those raised by the business leaders, think tanks, and politicians at the World Economic Forum. (Gregory, 2012, p. 3)

In line with postmodern and critical public relations scholars (e.g., Brown, 2012; Holzhausen, 2011; Pal \& Dutta, 2008), we find this conservative approach problematic because 20th century public relations theories have clear limits in tackling 21 st century global changes. Continuing to promote the use of such theories in current practice impedes the public relations profession from modernizing itself and truly contributing to the establishment of a 21 st century global society. Because of existing theories' normativity and their lack of consideration of the continuous changes in the environments in which public relations is embedded and to which it contributes, greater analysis and reflection must address how societies worldwide are changing.

Our review of societal changes focuses on four macro level changes occurring world-wide; we purposively exclude meso, i.e., how organizations are adapting, decoupling, or coupling with societal needs, and micro, i.e., how individuals and communities have changed/are changing. Because meso and micro levels are contextually contingent, it would be impossible to offer meaningful reflections on changes occurring at these levels within the scope of this article. Thus, we will examine four macro trends - social, political, economic, and cultural - that are overwhelmingly visible and interrelated in contemporary global society. We should caution, however, that predictions are precarious and outcomes are difficult to control. We must recognize that, in addition to constant change, unpredictable and sometimes chaotic changes can occur quickly within any of these trends.

\section{IDENTIFICATION OF PUBLICS AND ISSUES, NEW CHALLENGES AND ETHICAL CONSIDERATIONS}

Ironically, a global society has produced multi-vocality, challenging how public relations professionals identify publics and issues. Public relations' identification of publics and issues is a communicatively constituted activity, since it is through the analysis of expressed communications that public relations professionals identify who 
has concerns and what these concerns are. Yet social anomie may result in an era in which global communication is plentiful. The reasons? Communication becomes increasingly affordable, and messages are communicated rapidly and easily. Communication becomes overwhelming, not only in ease of access to information, but also with opportunities to join multiple online communities. The 21 st century global society requires redefinition and reconceptualization of how groups of individuals organize and form a "community" and what should be a "community" at a time when societal fragmentation will occur as opportunities increase for membership in multiple communities. Of concern also must be the increased opportunities for criminality and anarchy, which communication technology has enabled on a scale never before witnessed. Of course, what constitutes criminality and anarchy is open to definition and cultural interpretation, but at what point do opportunities for free speech instead create anarchy? Complex questions will arise about what can and perhaps should be done to control ubiquitous and inexpensive communication technology that fuels volatility with a potential for chaos that would have been inconceivable even a decade ago. Abuses and misuses - again, open to interpretation - can present immense dangers. Volatile publics can and will form immediately and unpredictably, irrespective of time and space, and these publics can act with immense power. It is impossible to reliably predict, let alone control, how publics will form, organize, and respond. Rather, those once possessing power may only be able to observe and to monitor and attempt to respond through dialog and negotiation.

Equally significantly, the concept of privacy will fundamentally change, with a total loss of personal privacy a distinct possibility. According to Facebook founder Mark Zuckerberg (cited in Johnson, 2010), the rise of online social networking sites means that people no longer have an expectation of privacy. During the past few years, "people have really gotten comfortable not only sharing more information and different kinds, but more openly and with more people". Trust will be present, but arguably may be misplaced, given the questionable security of personal information held by anonymous persons storing this information in the "cloud". Ubiquitous surveillance will be a part of all modern life, and, as evident from revelations about the activities of the United States National Security Agency, such surveillance could threaten democracy by altering the relationship between the people and their government (New York Times, 2013). Orwell's novel Nineteen Eighty-Four (1949/2004), about a hypothetical society having omnipresent government surveillance, seems less surreal than it was, particularly today when the Internet is considered by some to be a surveillance state (Schneier, 2013).

While paying lip service to personal privacy, social media also encourage more openness at personal, professional, and organizational levels. According to an annual report by the New Media Consortium's Horizon Project (De Santis, 2012), openness - as a concept that describes ideas such as open content, open data, and open resources, together with notions of transparency and easy access to data and information - is moving from a trend to a value for much of the world. Openness, 
however, can be problematic. To what extent, in the name of openness, shall organizations disclose information to publics? Does transparency have any boundaries? And, if so, what are they?

While there is no definitive answer to these questions, different positions have emerged. On the one hand, politicians, economists, and scientists are much more concerned about complete openness and its implications for societies. For example, Ehrmann and Fratzscher (2007), studying central bank communications, underscore the limits of transparency in relation to financial markets. They stress the need for communication to be flexible and to adjust to market conditions for central banks to achieve their ultimate objectives. Bioethical scholars Jansen and Sulmasy (2003) are also skeptical about promoting complete openness and transparency in relation to disclosing information about bioethical issues because such openness and transparency may create a "halo effect" on public opinion about a specific claim regarding an issue. On the other hand, we see other forces in society that push toward a different direction in transparency and openness. WikiLeaks, founded by Australian Internet activist Julian Assange, and the activist group Anonymous, which originated in 2003 as an online community, are examples of activist organizations in search of more transparency and openness of governments and corporations. These two organizations, however, have been seen as disruptive online communities that undermine the security of nations (Yost, 2010).

These issues should be understood from the perspective of the role of public relations in society, i.e., for promoting trust within a social system (cf. Valentini \& Kruckeberg, 2011), even in digital environments. Yet not all online public relations practices are transparent and open (Fitzpatrick \& Palenchar, 2006; Gower, 2006; Holladay \& Coombs, 2013), which, in turn, raises questions about the trustworthiness of online public relations intentions. Different phenomena, such as an increasing number of transparency requests by the public, coupled with an increasing use of new information and communication technologies, are forcing public relations professionals to re-consider: 1) their role as co-producers of information; 2) their role in devising organizational policies to meet different demands for openness and transparency while maintaining personal security and privacy; and 3) their duty toward a moral and democratic society.

\section{ACTIVISM AS A DISRUPTING SOCIAL SYSTEM FORCE}

The 21st century has witnessed growing activism around the world as a form of organized activity, often against power and hegemonic forces. Activism can be considered a sign of democratization and liberation for many, yet it substantially diverts social order, sometimes not with the best outcomes. Illustrating the diminishing power of nation-states over their citizenry are such events as the 2009 Iranian elections, the 2011 Arab Spring and London Riots, and, with less volatility but considerable traction, the Occupy Wall Street protests. More recent protests have 
occurred in Brazil and Egypt. Citizens organize, mobilize, and share information through the use of digital media such as smart phones. Digital media have become a tool for mobilizing public opinion in autocratic countries (Valentini \& Kruckeberg, 2012). They report breaking news much faster than do traditional journalistic media. They also influence political agendas and can change values. This bottomup process of shaping society has been defined by Beck (1994) as sub-politics, i.e., forms of politics outside and beyond the representative institutions of the political system of nation-states. A move toward democracy likely will be facilitated as never before. Criminality and anarchy may not be far behind. Such terrorist organizations as ISIS have developed strong networks of soldiers via the use of information and communication technologies.

Furthermore, power among nation-states in the global milieu may fundamentally change. Although they are "social actors", corporations, NGOs/civil society organizations, and governments are nevertheless politically defined and controlled. The constitutive and operational conceptual definitions of these three main social actors may require re-examination. Cammaerts observes that, in a mature democracy, apolitical groups and political institutions interplay and overlap:

The state is not an entity separated from society and neither is there a clear distinction between what is called civil society and institutional and formal politics. (2006, p. 266)

Even corporations, argues Cornelissen (2011), are part of this complex interplay because they are also part of local and global societies and are being asked more and more to take an active social role. Paradoxically, an active social role by corporations may result in a loss of political control by nation-states, whatever these nation-states' sense of accountability is to their citizens. Increasingly, this political control is being relinquished to transnational, i.e., global, corporations that often provide little transparency and accountability to the citizens of individual nation-states. An example is the case of the phone-hacking scandal involving the News of the World and other British tabloid newspapers published by News International. Employees of that newspaper were accused of engaging in phone hacking, police bribery, and exercising improper influence in the pursuit of publishing stories (BBC News, 2011).

Clearly, 21st century activism is disputing public relations' function of maintaining mutual and beneficial relations among diverse social actors in societies (Valentini \& Kruckeberg, 2011). At issue is what the role should be of public relations as a boundary-spanning organizational function that bridges society with organizations when activism is increasing and the three major social actors, all of which employ public relations professionals, need to collaborate to maintain working social systems. It may be time to acknowledge the possibility that, while the public relations profession has its origins in the world of capitalism (Berger, 2005), it may have a more promiscuous future with such social actors as governments and NGOs/civil society organizations - or it can take primary responsibility to increase corporate morality, responsibility, and commitment towards society. Recent 
corporate practices show that some corporations are acting as the "custodians" of social well-being in some countries. In other words, it is possible and sensible for corporations today to undertake social and political responsibilities that go beyond legal requirements. By doing so, corporations fill a regulatory hole in global governance (Scherer \& Palazzo, 2011; Scherer \& Smid, 2000; Vogel, 2007) and indirectly support the notion of public relations as a profession that is rooted in society and counsels organizations in giving back to society.

\section{BALANCING ECONOMIC INTERESTS WITH GLOBAL SOCIETY'S NEEDS}

In economic terms, globalization has substantively transformed the ways in which organizations and economic players operate. In particular, three main trends have been associated with globalization: 1) lower wages for workers throughout the world, together with higher corporate profits in Western economies; 2) a massive movement of migrants to cities in poor countries; and 3) low inflation and low interest rates, despite strong economic growth (Schifferes, 2007). Corporations necessarily take natural resources where they exist, e.g., petroleum and rare metals. Corporations then can employ labor where it is least expensive (and sometimes exploitative) and, taking these factors into account, pursue markets that are deemed most lucrative. Transnational, i.e., global, corporations can choose to be headquartered wherever it is most beneficial to them. Yet nation-states and their governmental agencies are sustained through taxes paid by corporations, as well as by individuals employed by these corporations. And nation-states, including governmental agencies, can operate only if they have sufficient resources.

An asymmetry in a sociological sense (see Coleman, 1982, for a discussion on asymmetric society) between societal forces can create an unstable social system (Valentini \& Kruckeberg, 2011), i.e., a society in which the three fundamental social actors, governments, NGOs/civil society organizations, and corporations do not equally support the weight of society (Kruckeberg, 2007; Valentini \& Kruckeberg, 2011). Kruckeberg $(1995,2007)$ argues that democratic societies can and will exist in the 21st century only through the support of and directly resulting from the cooperative community-building efforts of governments, NGOs/civil society organizations, and corporations. It is the corporations which not only provide goods and services, but also employment, a tax base, and other social benefits. Organizations that outsource or move their headquarters for strictly self-serving purposes undermine the stability and viability of their host countries and consequently instigate such phenomena as worker emigration, reduction of business in communities from which people are emigrating, and less wealth within the community. The result? Lower-quality public services and/or increasing costs for what was once "public service".

A global economic network means financial problems in one country or region quickly transcend to others, becoming a dire worldwide threat of considerable 
magnitude. An arguably more insidious threat is the economic enslavement that promotes consumerism and inducements for over-consumption to achieve an illusory happiness, pushing people into financial debt and tenuous situations. Mick and Fournier (1998, p. 126) describe the freedom/enslavement paradox in which technology's ability to facilitate independence and fewer restrictions can lead to dependence and more instructions. Rather than integrating technology into their lives, consumers integrate their lives into technology. Although consumers may adopt technology to simplify or enrich their lives, the use of a technology-based service may elicit the need for additional investments to use the service effectively.

Public relations professionals, together with marketing professionals, are chiefly responsible for such economic enslavement; although the latter have clearly admitted and have accepted that their professional credo is creating, promoting, and delivering goods and services to consumers and other stakeholders, the former (public relations professionals) suffer from what we call a "multiple personality disorder". Public relations has helped organizations promote this economic enslavement sometimes not admitting it and, at the same time, public relations has helped redeem corporations from such ill behavior by helping these corporations give back to society through corporate social responsibility initiatives. Yet increasing consumer skepticism shows that publics recognize the existence of these problems and become more immune to those corporate social responsibility initiatives (Crossley, 2003; Klein et al., 2004; Odou \& de Pechpeyrou, 2011). This "multiple personality disorder" is a professional identity issue that existing public relations theories barely confront. Most widely used definitions of public relations do not consider public relations a profession acting on behalf of society. Nor do they offer insights into the sociological implications of such "multiple personality disorders" for the profession in a global society.

Left without a clear normative theory of society that addresses the role of public relations, we wonder what role public relations will play in contemporary global society. Earlier, we asked whether public relations as a professionalized occupation contributes to the acceleration of the marketization of society (cf. Nichols, 2011; Pierre, 1995), i.e., a society in which anything can be measured through market criteria and can be exchanged for a market value, or whether public relations can facilitate a post-marketized society and ease today's uncertainties and increase trust among different social systems (Valentini \& Kruckeberg, 2011). In our view, public relations scholarship fails to offer normative grounds to help the profession balance economic interests with global society's needs.

\section{UNPREDICTABLE SOCIETAL VALUES AND MORES}

Finally, global society has furthered the development of unpredictable and everchanging social values and mores. Existing global public relations theories (Sriramesh \& Verčič, 2003, 2009) suggest that global public relations activities require 
the integration of societal values and mores. The question is how to integrate them when they are unpredictable and discordant. According to Valentini (2005), a society in search of understanding itself increasingly becomes involved in paradigms that mirror less the conditions of continuing formations and more the challenges of alteration. At a macro-level, the greatest social tension will be between modernity and traditionalism (Goankar, 2001; Portes, 1973; Simadi, 2006), the former in its continuing evolution and the latter in its several ideological variations. Modernity and traditionalism will continue to create a "clash of civilizations" requiring cultures to either co-exist, meld, or attempt to dominate one another in a world in which conflicting and changing concepts of what it means to be human (and humane) and in which the concept of the self may be fundamentally changing. Values and mores worldwide are being influenced in ways that are largely uncontrollable, that are oftentimes unpredictable, and that arguably may be deleterious (Chen \& Starosta, 2000; Moghadam, 2012). However, we can lose sight of the fact that beliefs and expectations change, not only over time, but also from one cultural environment to another (Valentini, 2005). People in different societies and milieus are different in how they live, work, and play and in how they adapt to their social environments (Bauer, 2006; Heath, 2006). As a result, people develop special needs and acquire peculiar habits and customs. Because people have different experiences and because words are the names that people give to their experiences, language differences are also created, which, in general, result in particular patterns and methods and forms of expression in how people relate to one another (Bauer, 2006; Valentini, 2005).

In a global society, therefore, contradicting forces of amalgamation and homogenization persist on the one side, and dispersion, individualization, and re-secularization on the other. According to Qvortrup (2003), communication technologies play a key role in this dichotomy because they promote "decentered processes of mutual observation and coordination among social sub-centers" (p. 4) and consequently allow the maintenance of a certain level of personalization, while at the same time allowing the amalgamation of values, mores, and norms. As a result, Simadi (2006) argues, modernity and traditionalism can coexist within the same social group. Thus, a total victory for modernity cannot be assumed. Powerful resistance will remain from those who long for the psychological security of traditionalism and of indigenous and psychological cultures that find traditionalism either reassuring or preferable to what modernity has to offer. In a twist of irony, people will be enabled in their quest for traditionalism by the communication technology that is available to them through modernity.

\section{SUGGESTIONS FOR FUTURE DIRECTIONS FOR PUBLIC RELATIONS}

We have explored some of today's ongoing macro trends that influence global society as well as the impact of digital technologies that shape the environment in 
which public relations professionals practice. Our thesis has been that 20th century public relations paradigms must be re-examined and challenged in a 21st century technological, global, and multicultural world. We claim that to understand the role of public relations in 21st century global societies, we first need to comprehend which factors at macro, meso, and micro levels lie beneath the substantial changes in today's global society. Our article has offered reflections on four macro level changes and how they challenge the public relations profession and its role in a global society.

Yet we need more scholarly work to better understand the dynamics of global society and the interplay of different phenomena occurring in contemporary societies to respond to questions about transparency and openness on the one hand and reputation and issue management on the other. More research is needed to illuminate:

[...] implications of globalization, interdependence, interconnection, global shifts in power, and complexity and the concomitant fallout such as the potential for inter-generational conflict, security, resource wars, and the inability of nations and organizations to deal with these issues. (Gregory, 2012, p. 3)

Public relations practitioners are expected to be well-equipped to cope with these challenges. However, their practice, role, and function, as well as their requisite education, must be re-examined in light of today's world. Fundamental questions persist, e.g., who will be the clients of public relations practitioners? Who will pay practitioners to perform their role? To whom will public relations practitioners be responsible? More broadly, is the 20th century organizational role of public relations optimal or even meaningful? Or, as appears more likely, is public relations at least partly dysfunctional during this time of rapid societal change? Will the four discussed trends in global society result in a continuing evolution of existing 20th century paradigms? Or will these trends produce a revolution in public relations scholarship and practice? The authors suggest, à la Thomas Kuhn (1970), that a "revolution" may not be necessary, but public relations paradigms should be reexamined and perhaps a "shift" attempted. Such a paradigmatic shift should not be exclusively or primarily Western in perspective, but should consider changes occurring in a global society as described earlier and must provide new directions for practicing public relations globally. In sum, a 21st century technological, global, and multicultural society requires continuing critical re-examination of the paradigms that have guided our thinking and actions.

Future research should start from an analysis of society and globalization and provide new ways for public relations to find a balance between different interests in society and the multi-faceted, often contradictory, expectations of the public toward organizations that public relations professionals represent (Heath, 2006). A challenge for future research is to provide epistemological and ontological meanings to the public relations profession without imposing colonialist indications of 
what is and is not acceptable for the practice. We believe that to define and orient its practices, public relations as a profession that is embedded in a sociological framework should start from the sociological presumption of being part of and at the service of a community. The concept of community, both in its macro understanding, i.e., global society, and its micro interpretation, i.e., a group of individuals sharing some commonalities, can offer different venues for discussing the role of public relations. This same concept of community constitutes the fundamental thesis of Kruckeberg and Starck (1988), later reiterated by Kruckeberg and Vujnovic (2005). We argue that the concept of community is still normatively germane today - although with some adjustments - to help public relations practitioners explain what should be their role in an organization and in society-at-large. Public relations professionals should not simply act as mediators between the external environment and the organizations they represent. Public relations should serve as a catalyst for promoting fruitful and constructive interactions among corporations, NGOs/civil society organizations, and governments. This means understanding the communities in which each of these groups function. Public relations scholars first must explore and critically evaluate positive models of society and then consider competing normative models of society and their supporting theories in light of these global trends. Within this framework, public relations and related concepts must be re-examined and possibly redefined and re-conceptualized, ranging from consideration of such fundamental concepts as publics, relationships, and organizations, as well as other concepts essential to public relations theory-building. Essentially, we are advocating new conceptualizations that a normative theory of society and a heuristic meta-theory of public relations demand. With such scholarly inquiry and process, paradigm shifts - and possibly new paradigms in public relations - are likely to emerge and provide a new foundation for public relations practice in a 21 st century global society.

\section{REFERENCES}

Bardhan, N. (2011). Culture, communication and third culture building in public relations within global flux. In: Bardhan, N., Weaver, C.K. (eds.). Public Relations in Global Cultural Contexts. Multi-paradigmatic Perspectives. New York, NY: Routledge, pp. 77-107.

Bardhan N., Weaver, C.K. (eds.). (2011). Public Relations in Global Cultural Contexts. Multi-paradigmatic Perspectives. New York, NY: Routledge.

Bauer, T.A. (2006). Culture of diversity. A theoretical concept towards transcultural understanding. In: Bauer, T.A., Ortner, G.E. (eds.). Werte für Europa. Medienkultur und Ethische Bildung in und für Europa. Düsseldorf, Germany: B+B Medien, pp. 242-267.

BBC News. (2011). Phone-hacking Scandal: Timeline. Retrieved May 30, 2013 from http://www.bbc. co.uk/news/uk-14124020.

Beck, U. (1994). The reinvention of politics: Towards a theory of reflexive modernisation. In: Beck, U., Giddens, A., Lash, S. (eds.). Reflexive Modernization: Politics, Tradition and Aesthetics in the Modern Social Order. Cambridge, UK: Polity Press, pp. 1-55. 
Berger, B.K. (2005). Power over, power with, and power to relations: Critical reflections of public relations, the dominant coalition, and activism. Journal of Public Relations Research, 17, pp. 5-28.

Berger, P.L. (2002). Introduction. The cultural dynamics of globalization. In: Berger, P.L., Huntington, S.P. (eds.). Many Globalizations: Cultural Diversity in the Contemporary World. Oxford, UK: Oxford University Press, pp. 1-16.

Brown, R.E. (2012). Epistemological modesty: Critical reflections on public relations thought. Public Relations Inquiry, 1 (1), pp. 89-105.

Cammaerts, B. (2006). Media and communication strategies of glocalized activists: Beyond mediacentric thinking. In: Cammaerts, B., Carpentier, N. (eds.). Reclaiming the Media: Communication Rights and Expanding Democratic Media Roles. ECREA book series. Bristol, UK: Intellect, pp. 265-288.

Castells, M. (2008). The new public sphere: Global civil society, communication networks, and global governance. The ANNALS of the American Academy of Political and Social Science, 616 (1), pp. 78-93.

Chen, G.M., Starosta, W.J. (2000). Communication and Global Society. New York, NY: Peter Lang.

Coleman, J. (1982). The Asymmetric Society. Syracuse, NY: Syracuse University Press.

Coombs, T.W. (1998). The internet as potential equalizer: New leverage for confronting social irresponsibility. Public Relations Review, 24 (3), pp. 289-303.

Coombs, T.W. (2002). Assessing online issue threats: Issue contagions and their effect on issue prioritization. Journal of Public Affairs, 2 (4), pp. 215-229.

Coombs, T.W., Holladay, S.J. (2012). Amazon.com's Orwellian nightmare: Exploring apology in an online environment. Journal of Communication Management, 16 (3), pp. 280-295.

Cornelissen, J. (2011). Corporate Communication. A Guide to Theory and Practice. Thousand Oaks, CA: Sage.

Crossley, N. (2003). Even newer social movements? Anti-corporate protests, capital crises and the remoralization of society. Organization, 10, pp. 287-305.

Curtin, P., Gaither, K.T. (2007). International Public Relations: Negotiating Culture, Identity, and Power. Thousand Oaks, CA: Sage.

De Santis, N. (2012). New media consortium names 10 Top "Metatrends" shaping educational technology. The Chronicle of Higher Education, February 1. Retrieved May 30, 2013 from http:// chronicle.com/blogs/wiredcampus/new-media-consortium-names-10-top-metatrends-shaping-educational-technology/35234.

Dutta, M.J. (2012). Critical interrogations of global public relations. In: Sriramesh, K., Verčič, D. (eds.). Culture and Public Relations. Links and Implications. New York: Routledge, pp. 202-217.

Edwards, L. (2012). Defining the "object" of public relations research: A new starting point. Public Relations Inquiry, 1 (1), pp. 7-30.

Edwards, L., Hodges, C.E.M. (2011). Public Relations, Society, and Culture: Theoretical and Empirical Explorations. London, UK: Routledge.

Ehrmann, M., Fratzscher, M. (2007). Social value of public information - Testing the limits to transparency. European Central Bank, working paper series, no. 821/October. Retrieved May 30, 2013 from http://www.ecb.int/pub/pdf/scpwps/ecbwp821.pdf.

Featherstone, M., Lash, S., Robertson, R. (1995). Global Modernities. London, UK: Sage.

Fitzpatrick, K.R., Palenchar, M. (2006). Disclosing special interests: Constitutional restrictions on front groups. Journal of Public Relations Research, 18 (3), pp. 203-224.

Giddens, A. (1990). The Consequences of Modernity. Stanford, CA: Stanford University Press.

Goankar, D.P. (2001). Alternative Modernities. Durham, NC: Duke University Press.

Gower, K.K. (2006). Truth and transparency. In: Fitzpatrick, K., Bronstein, C. (eds.). Ethics in Public Relations: Responsible Advocacy. Thousand Oaks, CA: Sage, pp. 89-106. 
Gregory, A. (2012). Reviewing public relations research and scholarship in the 21st century. Public Relations Review, 38 (1), pp. 1-4.

Heath, R.L. (2006). Onward into more fog: Thoughts on public relations' research directions. Journal of Public Relations Research, 18 (2), pp. 93-114.

Hodges, C. (2012). The meaning(s) and making(s) of PR: The potential of ethnography within PR research. In: Carayol, V., Frame, A. (eds.). Communicating PR from a Cross-cultural Standpoint. Practical and Methodological Issues. Brussels, Belgium: Peter Lang, pp. 99-113.

Holladay, S.J., Coombs, W.T. (2013). Public relations literacy: Developing critical consumers of public relations. Public Relations Inquiry, 2 (2), pp. 125-146.

Holtzhausen, D. (2011). The need for a postmodern turn in global public relations. In: Bardhan, N., Weaver, C.K. (eds.). Public Relations in Global Cultural Contexts. New York, NY: Routledge, pp. $140-167$.

Ihlen, Ø., van Ruler, B., Fredriksson, M. (eds.). (2009). Public Relations and Social Theory: Key Figures and Concepts. New York, NY: Routledge.

Jansen, L.A., Sulmasy, D.P. (2003). Bioethics, conflicts of interest, the limits of transparency. The Hastings Center Report, 33 (4), pp. 40-43.

Johnson, B. (2010). Privacy no longer a social norm, says Facebook founder. The Guardian, January 10. Retrieved May 30, 2013 from http://www.guardian.co.uk/technology/2010/jan/11/facebook-privacy.

Kent, M.L. (2010). Chapter 45: Directions in social media for professionals and scholars. In: Heath, R.L. (ed.). The SAGE Handbook of Public Relations. London, UK: Sage, pp. 643-656.

Kent, M., Taylor, M. (2011). How IC theory informs public relations practice in global settings. In: Bardhan, N., Weaver, C.K. (eds.). Public Relations in Global Cultural Contexts. New York, NY: Routledge, pp. 50-77.

Klein, J.G., Smith, N.C., John, A. (2004). Why we boycott: Consumer motivations for boycott participation. Journal of Marketing, 68, pp. 92-109.

Kruckeberg, D. (1995). The challenge for public relations in the era of globalization. Public Relations Quarterly, 40 (4), pp. 36-39.

Kruckeberg, D. (2007). An "organic model" of public relations: The role of public relations for governments, civil society organizations (CSOs) and corporations in developing and guiding social and cultural policy to build and maintain community in 21 st-Century civil society. In: The Administration of Ulan-Ude Committee of Social Politics (eds.). Municipal Social Politics and the Publics: Realities and Perspectives: Materials of the International/Scientific Conference. UlanUde, Buryatia: Publishing House of Buryatia Scientific Center of Russian Academy of Science, pp. 17-25.

Kruckeberg, D., Starck, K. (1988). Public Relations and Community: A Reconstructed Theory. New York, NY: Praeger.

Kruckeberg, D., Vujnovic, M. (2005). Imperative for an Arab model of public relations as a framework for diplomatic, corporate and nongovernmental organization relationships. Public Relations Review, 31 (3), pp. 338-343.

Kuhn, T.S. (1970). The Structure of Scientific Revolutions. Chicago, IL: The University of Chicago Press.

L'Etang, J. (2008). Public Relations: Concepts, Practice and Critique. London, UK: Sage.

L'Etang, J. (2012). Thinking about public relations and culture: Anthropological insights and ethnographic futures. In: Sriramesh, K., Verčič, D. (eds.). Culture and Public Relations. Links and Implications. New York, NY: Routledge, pp. 218-237.

McKie, D., Munshi, D. (2009). Theoretical black holes: A partial A to Z of missing critical thought in public relations. In: Heath, R.L., Toth, E., Waymer, D. (eds.). Rhetorical and Critical Approaches to Public Relations II. New York, NY: Routledge, pp. 61-75. 
Mick, D.G., Fournier, S. (1998). Paradoxes of technology: Consumer cognizance, emotions, and coping strategies. Journal of Consumer Research, 25, pp. 123-143.

Moghadam, V.M. (2012). Globalization and Social Movements: Islamism, Feminism, and the Global Justice Movement (2nd ed). London, UK: Rowman \& Littlefield Publishers.

Moreno, A., Verhoeven, P., Tench, R., Zerfass, A. (2014). Increasing power and taking a lead — What are practitioners really doing? Empirical evidence from European communications managers (Incrementar el poder y asumir el liderazgo - ¿Qué hacen realmente los profesionales? Evidencias empíricas sobre los gestores de comunicación en Europa). Revista Internacional De Relaciones Publicas, 4 (7), pp. 73-94.

New York Times. (2013). Surveillance: A threat to democracy. Retrieved June 11, 2013 from http:// www.nytimes.com/2013/06/12/opinion/surveillance-a-threat-to-democracy.html?_r=0.

Nichols, L.T. (2011). Public Sociology: The Contemporary Debate. New Brunswick, NJ: Transaction Publishers.

Odou, P., Pechpeyrou, P. (2011). Consumer cynicism. From resistance to anti-consumption in a disenchanted world? European Journal of Marketing, 45 (11/12), pp. 1799-1808.

Orwell, G. (1949/2004). Nineteen Eighty-Four. London, UK: Penguin Books Limited.

Pal, M., Dutta, M. (2008). Public relations in a global context: The relevance of critical modernism as a theoretical lens. Journal of Public Relations Research, 20 (2), pp. 159-179.

Pierre, J. (1995). The marketization of the state: Citizens, consumers, and the emergence of the public market. In: Peters, B.G., Savoie, D.J. (eds.). Governance in a Changing Environment. Quebec, Canada: McGill-Queen's Press, pp. 55-81.

Portes, A. (1973). Modernity and development: A critique. Studies in Comparative International Development, 8 (3), pp. 247-279.

Qvortrup, L. (2003). The Hypercomplex Society. New York, NY: Peter Lang.

Radford, G.P. (2012). Public relations in a postmodern world. Public Relations Inquiry, 1 (1), pp. 49-67.

Rittenhofer, I., Valentini, C. (2015). A practice turn to global public relations: An alternative approach. Journal of Communication Management, 19 (1), pp. 2-19.

Robertson, R. (1992). Social Theory and Global Culture. London, UK: Sage.

Schifferes, S. (2007). Globalisation shakes the world. BBC News, January 21. Retrieved May 30, 2013 from http://news.bbc.co.uk/2/hi/business/6279679.stm.

Shome, R., Hedge, R. (2002). Culture, communication, and the challenge of globalization. Critical Studies in Media Communication, 19 (2), pp. 172-189.

Scherer, A.G., Palazzo, G. (2011). The new political role of business in a globalized world: A review of a new perspective on CSR and its implications for the firm, governance, and democracy. Journal of Management Studies, 48 (4), pp. 899-931.

Scherer, A.G., Smid, M. (2000). The downward spiral and the U.S. model principles. Why MNEs should take responsibility for the improvement of world-wide social and environmental conditions. Management International Review, 40, pp. 351-371.

Schneier, B. (2013, March 16). The Internet is a surveillance state. CNN Opinion. Retrieved May 30, 2013 from http://edition.cnn.com/2013/03/16/opinion/schneier-internet-surveillance/index. html?sr=sharebar_facebook.

Scholte, J.A. (2000). Globalization: A Critical Introduction. New York, NY: St. Martin's Press.

Simadi, F.A. (2006). The United Arab Emirates Youths (UAEU) between modernity and traditionalism. International Journal of Sociology and Social Policy, 26 (3/4), pp. 172-184.

Sriramesh, K., Verčič, D. (2003). The Global Public Relations Handbook. Theory, Research and Practice. Mahwah, NJ: Lawrence Erlbaum.

Sriramesh, K., Verčič, D. (2009). The Global Public Relations Handbook. Theory, Research and Practice. Expanded and Revised Edition. New York, NY: Routledge. 
Taylor, M. (2000). Toward a public relations approach to nation building. Journal of Public Relations Research, 12 (2), pp. 179-210.

Taylor, M. (2010). Public relations in the enactment of civil society. In: Heath, R.L. (ed.). The SAGE Handbook of Public Relations. Thousand Oaks, CA: Sage, pp. 5-16.

Taylor, M., Doerfel, M.L. (2003). Building interorganizational relationships that build nations. Human Communication Research, 29 (2), pp. 153-181.

Tomlinson, J. (1999). Globalization and Culture. Chicago, IL: University of Chicago Press.

Valentini, C. (2005). The European odyssey: Communication of cultures vs. culture of communication. In: First European Communication Conference "Fifty Years of Communication Research in Europe: Past and Future". Amsterdam, The Netherlands: KIT, 24-26 November.

Valentini, C. (2007). Global versus cultural approaches in public relationship management: The case of the European Union. Journal of Communication Management, 11 (2), pp. 117-133.

Valentini, C. (2015). Is using social media "good" for the public relations profession? A critical reflection. Public Relations Review, 41 (2), pp. 170-177.

Valentini, C., Kruckeberg, D. (2011). Public relations and trust in contemporary global society: A Luhmannian perspective of the role of public relations in enhancing trust among social systems. Central European Journal of Communication, 4 (1), pp. 91-107.

Valentini, C., Kruckeberg, D. (2012). "Iran's Twitter revolution" from a public relations standpoint. In: George, A., Pratt, C. (eds.). Case Studies in Crisis Communication: International Perspectives on Hits and Misses. New York, NY: Routledge, pp. 383-402.

Verčič, D., Zerfass, A., Wiesenberg, M. (2015). Global public relations and communication management: A European perspective. Public Relations Review, 41 (5), pp. 785-793.

Vogel, D. (2007). Private global business regulation. Annual Review of Political Science, 11, pp. $261-$ 282.

Vujnovic, M., Kruckeberg, D. (2011). Managing global public relations in the new media environment. In: Deuze, M. (eds.). Managing Media Work. Thousand Oaks, CA: Sage, pp. 217-224.

Weaver, K. (2011). Public relations, globalization, and culture: Framing methodological debates and future directions. In: Bardhan, N., Weaver, C.K. (eds.). Public Relations in Global Cultural Contexts. Multi-paradigmatic Perspectives. New York, NY: Routledge, pp. 250-275.

Ye, L., Ki, E.J. (2012). The status of online public relations research: An analysis of published articles in 1992-2009. Journal of Public Relations Research, 24 (5), pp. 409-434.

Yost, P. (2010, November 29). Holder says WikiLeaks under criminal investigation. The Guardian. Retrieved May 30, 2013 from http://www.guardian.co.uk/world/feedarticle/938. 